\title{
Hepatitis A, B and C seropositivity among first-year healthcare students in western Turkey: a seroprevalence study
}

\author{
Ayla Acikgoz ${ }^{1 *}$ D, Dilek Cimrin ${ }^{1}$, Servet Kizildag ${ }^{1}$, Nuran Esen², Pinar Balci ${ }^{3}$ and Ayca Arzu Sayiner ${ }^{2}$
}

\begin{abstract}
Background: The risk of viral hepatitis among healthcare students (HCSS) is greater than that among the general population. Therefore, this study was conducted to investigate the seroprevalence of the hepatitis A virus (HAV), hepatitis B virus (HBV) and hepatitis C virus (HCV) among first-year HCSS at a university in Turkey and as a secondary objective, to determine the factors associated with HAV and HBV seropositivity.
\end{abstract}

Methods: This cross-sectional study was performed in first-year HCSs in Izmir, western Turkey. Data were collected using a self-administered questionnaire including items on sociodemographic characteristics, medical history, and hygiene. A total of $650 \mathrm{HCSs}$ were tested for the HAV, HBV and HCV markers. Categorical variables were compared using the chi-square test. The association between independent variables and anti-HAV seropositivity and anti-HBs seropositivity was assessed by multinomial logistic regression analysis.

Results: The overall frequency of total anti-HAV seropositivity was 34.9\%. HBsAg, total anti-HBC and anti-HBs seropositivity were found in 0.3, 1.2 and $93.7 \%$ of samples, respectively. All of the HCSs were negative for anti-HCV. Total anti-HAV seropositivity was found to be 1.73 times higher in those $\geq 21$ years old, and it was 1.61 times higher in those who perceived their economic status to be average and 2.75 times higher in those who perceived their economic status to be low. Total anti-HAV seropositivity was found to be 4.37 times higher in those who lived in provinces with intermediate human development index levels. Total anti-HBs seropositivity was found to be 2.48 times higher in those $\leq 20$ years old, and it was 2.13 times higher in those who perceived their economic status to be average.

Conclusions: Approximately two out of three HCSs were susceptible to HAV infection. Since HCSs are at high risk for HAV infection, they should be vaccinated before medical clerkships begin. Our results indicate that there is a high prevalence of anti-HBs seropositivity among HCSs. This result may be largely attributed to the implementation of a successful vaccination program in Turkey since 1998.

Keywords: Hepatitis A, Hepatitis B, Seroprevalence, Healthcare students

\footnotetext{
* Correspondence: ayla.acikgoz@deu.edu.tr

'Vocational School of Healthcare, Dokuz Eylul University, Balcova, 35340 Izmir, Turkey

Full list of author information is available at the end of the article
}

(C) The Author(s). 2020 Open Access This article is licensed under a Creative Commons Attribution 4.0 International License, which permits use, sharing, adaptation, distribution and reproduction in any medium or format, as long as you give appropriate credit to the original author(s) and the source, provide a link to the Creative Commons licence, and indicate if changes were made. The images or other third party material in this article are included in the article's Creative Commons licence, unless indicated otherwise in a credit line to the material. If material is not included in the article's Creative Commons licence and your intended use is not permitted by statutory regulation or exceeds the permitted use, you will need to obtain permission directly from the copyright holder. To view a copy of this licence, visit http://creativecommons.org/licenses/by/4.0/ The Creative Commons Public Domain Dedication waiver (http://creativecommons.org/publicdomain/zero/1.0/) applies to the data made available in this article, unless otherwise stated in a credit line to the data. 


\section{Background}

Health care workers (HCWs) may be exposed to viruses such as the hepatitis $B$ virus (HBV) and hepatitis $C$ virus $(\mathrm{HCV})$ in hospital environments. There are various contamination routes, such as accidental needlestick injury or exposure to infected blood, semen, and other body fluids $[1,2]$. Since healthcare students (HCSs) spend periods of time in hospitals during their education, they are at risk for hepatitis virus infections.

Hepatitis A virus (HAV) causes acute viral hepatitis. The reported incidence of HAV infection is approximately 1.4 million cases worldwide. While hepatitis A is often asymptomatic in children, it can become a serious, even deadly, disease in adolescents and adults [3].

Improvements in hygiene and socioeconomic conditions worldwide have resulted in lower disease incidence. HAV infection has moderate endemicity in Turkey $[4,5]$. It is emphasized by the World Health Organization (WHO) that comprehensive vaccination studies are useful in countries with moderate endemic levels for HAV infection incidence [4]. HAV infection is a vaccine-preventable disease that can be widely prevented by immunization strategies during childhood. Since 2012, the Ministry of Health has added the HAV vaccine to the mandatory childhood vaccine schedule in Turkey. The HAV is primarily transmitted through water, food and direct contact with an infected person. Theoretically, HCWs have a higher chance of direct contact with patients infected with hepatitis $\mathrm{A}$ and are at a higher risk than the general population. The HAV vaccine is recommended for HCWs in Turkey by the Ministry of Health [6]. Students who have studied in the health field have the potential to come into contact with patients carrying contagious diseases. Therefore, HCSs who have not had HAV infection or vaccination are at risk for HAV infection [1]. Either at the beginning of education or before clinical training, HCSs should be screened for hepatitis A.

The HBV and $\mathrm{HCV}$ are among the main causes of liver cirrhosis and hepatocellular carcinoma [1, 3]. These viruses cause public health problems worldwide. The WHO estimated that there were 257 million people with chronic HBV infection and 71 million people with chronic HCV infection worldwide in 2015. The prevalence of $\mathrm{HBV}$ infection is $3.5 \%$ worldwide [3]. The prevalence of $\mathrm{HBV}$ in Turkey varies according to the region (2-8\%) and increases from west to east. The prevalence of HBV in the general population in Turkey is higher than that in European countries [7-9].

In the past three decades, public health programs to control viral hepatitis infections have been carried out successfully [3]. One of the most effective public health programs to prevent $\mathrm{HBV}$ infection is the HBV vaccination program [1]. The national HBV vaccination program in Turkey began in July 1998. The Ministry of
Health has added the HBV vaccine to the mandatory childhood vaccine schedule in Turkey.

HCSs, like HCWs, may be at risk for HBV and HCV infections due to the increased threat of needlestick injury. The HBV vaccine is recommended in high-risk groups, such as HCWs and HCSs [1]. In Turkey, it is obligatory for HCWs to undergo a hepatitis B serology screening before starting their practice and to get the hepatitis $B$ vaccine if they are negative for anti-HBs. However, such a requirement is not yet available for HCSs.

Vaccination of HCSs is important to protect HCSs from hepatitis virus infections. However, it is unclear whether HCSs are vaccinated against hepatitis viruses. Therefore, this study was conducted to investigate the seroprevalence of HAV, HBV, and HCV among firstyear HCSs in a university in Turkey and, as a secondary objective, to determine the factors associated with HAV and HBV seropositivity.

\section{Methods}

\section{Study population}

This cross-sectional study was performed between April 2018 and July 2018 in first-year HCSs at Dokuz Eylul University Health Campus in the following schools: School of Physical Therapy and Rehabilitation, Faculty of Nursing, and Vocational School of Healthcare. The Dokuz Eylul University Health Campus is in Izmir, Western Turkey. All first-year students were invited to participate in the study, with no sampling. Ninety-eight students declined to participate in the study. As a result, a total of 650 firstyear HCSs participated in this study.

\section{Data collection}

Data were collected using a self-administered questionnaire, which included sociodemographic characteristics, self-reported vaccination history against HAV and HBV, perceived economic position, place of residence before attending university, main source of water in the household, residence in a house that had a sewage system, and presence of an $\mathrm{HCW}$ in the household. The provinces where the students lived before attending university were used for calculating the Human Development Index (HDI).

\section{Sample collection and laboratory analysis}

Venous blood samples $(7-9 \mathrm{ml})$ were collected from every participant. Samples were centrifuged at 10,000 rpm for $10 \mathrm{~min}$, and the sera were removed. During the measurements, laboratory personnel were blinded.

The serological markers were detected by enzymelinked immunosorbent assay (ELISA) using Architect kits on an Architect plus i2000 SR (Architect Systems and Abbot Diagnostics Division, USA). 
Total anti-HAV S/CO values $\geq 1.0$, $\mathrm{HBsAg} \mathrm{S} / \mathrm{CO}$ values $\geq 1.0$, anti-HBs concentrations $\geq 10 \mathrm{mIU} / \mathrm{mL}$, total anti-HBc S/CO values $\geq 1.0$, anti-HCV S/CO values $\geq 1.0$ were considered positive, and samples below these thresholds were considered negative according to the manufacturer's instructions.

\section{Ethical considerations}

The study was conducted in accordance with the principles of the Helsinki Declaration. Ethical approval was obtained from the Clinical Research Ethics Committee of Dokuz Eylül University, Izmir, Turkey. Participants were informed of their rights, including the right to refuse to sign the consent form, the right to withdraw their consent from the study at any time, and the right to participant confidentiality, before signing the informed consent form.

\section{Statistical analysis}

Continuous variables are presented as the mean and standard deviation. Categorical variables are presented as a number and frequency and $95 \%$ confidence intervals (95\% CI) and compared using the chi-square test. The association between independent variables that were found to be statistically significant by the chi-square test and anti-HAV seropositivity and anti-HBs seropositivity was assessed by multinomial logistic regression analysis. Statistical analyses were performed using Statistical Package for Social Sciences Version 20.0 (IBM Corp., Armonk, NY, USA). A value of $p<0.05$ was considered statistically significant.

\section{Results}

A total of 650 HCSs participated in the study and were tested for HAV, HBV and HCV markers. The majority of students were female $(n=432,66.5 \%)$. The age of the HCSs ranged from 18 to 37 years with an average of $19.8 \pm 2.1$ years. HCSs included 77 physiotherapy students (11.8\%), 234 nursing students (36.0\%) and 339 vocational school students (52.2\%).

The seropositivity for total anti-HAV in HCSs was $34.9 \%$. HBsAg was detected in two students $(0.3 \%)$ in this study. Only $1.2 \%$ of the students were serologically positive for total anti-HBc. Six hundred and nine (93.7\%) of the participants were found to be positive for antiHBs. As a result, $6.3 \%$ of the students were serologically negative for anti-HBs, indicating that they were not immune and were susceptible to infection. All of the HCSs were negative for anti-HCV (Table 1).

We observed significantly higher anti-HAV seropositive results in males than in females. In addition, the prevalence of anti-HAV seropositivity was significantly higher in students $\geq 21$ years, in low and average perceived economic position groups, and in those living in provinces with intermediate HDI levels before attending university $(p<0.05)$. Total anti-HAV seropositivity was higher in subjects who lived in a house without a sewage system $(p<0.05)$ (Table 2).

The prevalence of anti-HBs seropositivity was significantly higher in students $\leq 20$ years, in low and average perceived economic position groups, in those who lived in provinces with intermediate HDI levels before attending university and in those with a self-reported HBV vaccination history $(p<0.05)$. There was no association between anti-HBs seropositivity and sex or area of childhood residence (Table 3).

Total anti-HAV seropositivity was found to be 1.73 times higher in those $\geq 21$ years old than in those $\leq 20$ years old (OR: $1.73,95 \% \mathrm{CI}=1.05-1.86$ ), and it was 1.61 times higher in those who perceived their economic status to be average (OR: $1.61,95 \% \mathrm{CI}=1.01-2.58)$ and 2.75 times higher in those who perceived their economic status to be low (OR: $2.75,95 \% \mathrm{CI}=1.31-5.79$ ) than in those who perceived their economic status to be high. Total anti-HAV seropositivity was found to be 4.37 times higher in those who lived in provinces with intermediate HDI levels before attending university than in those living in provinces with high HDI levels before attending university (OR: 4.37, 95\% CI = 3.00-6.38) (Table 4).

Total anti-HBs seropositivity was found to be 2.48 times higher in those $\leq 20$ years old than in those $\geq 21$ years old (OR: $2.48,95 \% \mathrm{CI}=1.16-5.29$ ), and it was 2.13 times higher in those who perceived their economic status to be average than in those who perceived their economic status to be high (OR: $2.13,95 \% \mathrm{CI}=1.07-4.24$ ). Total anti-HBs seropositivity was found to be 8.23 times higher in those who reported HBV vaccination history than in those who did not report a vaccination history (OR: 8.23, 95\% CI = 2.08-32.62) (Table 4).

\section{Discussion}

A total of 650 HCSs participated in this study and were tested for the HAV, HBV and HCV markers. The

Table 1 Prevalence of hepatitis A, B and C seropositivity according to sex among healthcare students $(n=650)$

\begin{tabular}{llllll}
\hline Sex & Total anti- HAV $n(\%)$ & HBsAg $n(\%)$ & Total anti-HBc $n(\%)$ & Anti-HBs $n(\%)$ & Anti-HCV $n(\%)$ \\
\hline Male & $100(45.9)^{*}$ & 0 & $5(2.3)$ & $208(95.4)$ & 0 \\
Female & $127(29.4)$ & $2(0.5)$ & $3(0.7)$ & $401(92.8)$ & 0 \\
Total & $227(34.9)$ & $2(0.3)$ & $8(1.2)$ & $609(93.7)$ & 0 \\
$n(\%)$ & & & & &
\end{tabular}


Table 2 Association between demographic features and the prevalence of total anti-HAV seropositivity among healthcare students $(n=650)$

\begin{tabular}{|c|c|c|c|c|c|c|}
\hline Variables & & Total $n$ & Positive $\mathrm{n}(\%)$ & Negative n (\%) & Odds Ratio (Cl 95\%) & $\boldsymbol{p}$-value \\
\hline \multirow[t]{2}{*}{ Sex } & Male & 218 & $100(45.9)$ & $118(54.1)$ & $2.03(1.45-2.85)$ & $<0.001$ \\
\hline & Female & 432 & $127(29.4)$ & $305(70.6)$ & Ref. & \\
\hline \multirow[t]{2}{*}{ Age group (years) } & $\geq 21$ & 93 & $42(45.2)$ & $51(54.8)$ & $1.65(1.05-2.58)$ & 0.014 \\
\hline & $\leq 20$ & 557 & $185(33.2)$ & $372(66.8)$ & Ref. & \\
\hline \multirow[t]{3}{*}{ Perceived economic position } & Low & 52 & $30(57.7)$ & $22(42.3)$ & $4.81(2.45-9.58)$ & $<0.001$ \\
\hline & Average & 452 & $165(36.5)$ & $287(63.5)$ & $2.04(1.33-3.20)$ & $<0.001$ \\
\hline & High & 146 & $32(21.9)$ & $114(78.1)$ & Ref. & \\
\hline \multirow[t]{3}{*}{ Water source } & City water & 46 & $18(39.1)$ & $28(60.9)$ & $1.20(0.56-2.51)$ & 0.313 \\
\hline & Licenced-wrapped water & 515 & 178 (34.6) & $337(65.4)$ & $0.98(0.61-1.59)$ & 0.477 \\
\hline & Well water & 89 & $31(34.8)$ & $58(65.2)$ & Ref. & \\
\hline \multirow[t]{2}{*}{ House that has the sewage system } & No & 134 & $63(47.0)$ & $71(53.0)$ & $1.90(1.29-2.80)$ & $<0.001$ \\
\hline & Yes & 516 & $164(31.8)$ & $352(68.2)$ & Ref. & \\
\hline \multirow[t]{3}{*}{ Childhood residence } & Districts & 275 & $93(33.8)$ & $182(66.2)$ & $1.02(0.70-1.51)$ & 0.441 \\
\hline & Country & 170 & $66(38.8)$ & $104(61.2)$ & $1.27(0.83-1.95)$ & 0.129 \\
\hline & Province & 205 & $68(33.2)$ & $137(66.8)$ & Ref. & \\
\hline \multirow[t]{2}{*}{ Human development index } & Intermediate & 218 & $132(60.6)$ & $86(39.4)$ & $5.42(3.81-7.76)$ & $<0.001$ \\
\hline & High & 432 & $95(22.0)$ & $337(78.0)$ & Ref. & \\
\hline \multirow[t]{3}{*}{ Self-reported HAV vaccination history } & No & 102 & $44(43.1)$ & $58(56.9)$ & $1.38(0.72-2.65)$ & 0.162 \\
\hline & Unknown & 483 & $160(33.1)$ & $323(66.9)$ & $0.90(0.52-1.57)$ & 0.356 \\
\hline & Yes & 65 & $23(35.4)$ & 42 (64.6) & Ref. & \\
\hline
\end{tabular}

Table 3 Association between subject characteristics and the prevalence of anti-HBs seropositivity among healthcare students ( $n=650$ )

\begin{tabular}{|c|c|c|c|c|c|c|}
\hline Variable & & Total $n$ & Positive n (\%) & Negative n (\%) & Odds Ratio (Cl 95\%) & $\boldsymbol{p}$-value \\
\hline \multirow[t]{2}{*}{ Sex } & Female & 432 & $401(92.8)$ & $31(7.2)$ & Ref. & \\
\hline & Male & 218 & $208(95.4)$ & $10(4.6)$ & $1.60(0.78-3.49)$ & 0.202 \\
\hline \multirow[t]{2}{*}{ Age group (years) } & $\geq 21$ & 81 & $81(87.1)$ & $12(12.9)$ & Ref. & \\
\hline & $\leq 20$ & 557 & $528(94.8)$ & $29(5.2)$ & $2.69(1.27-5.43$ & 0.010 \\
\hline \multirow[t]{3}{*}{ Perceived economic position } & High & 146 & $130(89.0)$ & $16(11.0)$ & Ref. & \\
\hline & Average & 452 & $428(94.7)$ & $24(5.3)$ & $2.19(1.10-4.24)$ & 0.024 \\
\hline & Low & 52 & $51(98.1)$ & $1(1.9)$ & $6.24(1.07-135.4)$ & 0.038 \\
\hline \multirow[t]{3}{*}{ Childhood residence } & Province & 205 & $188(91.7)$ & $17(8.3)$ & Ref. & \\
\hline & Districts & 275 & $263(95.6)$ & $12(4.4)$ & $1.97(0.92-4.35)$ & 0.080 \\
\hline & Country & 170 & $158(92.9)$ & $12(7.1)$ & $1.19(0.55-2.63)$ & 0.665 \\
\hline \multirow[t]{2}{*}{ Presence of an HCW in the household } & No & 549 & $513(93.4)$ & $36(6.6)$ & Ref. & \\
\hline & Yes & 101 & $96(95.0)$ & $5(5.0)$ & $1.34(0.54-3.95)$ & 0.570 \\
\hline \multirow[t]{2}{*}{ Human development index } & High & 432 & $398(92.1)$ & $34(7.9)$ & Ref. & \\
\hline & Intermediate & 218 & $211(96.8)$ & $7(3.2)$ & $2.57(1.16-6.36)$ & 0.017 \\
\hline \multirow[t]{3}{*}{ Self-reported HBV vaccination history } & No & 77 & 69 (89.6) & $8(10.4)$ & Ref. & \\
\hline & Yes & 194 & $191(98.5)$ & $3(1.5)$ & $7.31(1.94-34.94)$ & 0.002 \\
\hline & Unknown & 379 & $349(92.1)$ & $30(7.9)$ & $1.34(0.55-2.99)$ & 0.472 \\
\hline
\end{tabular}


Table 4 Association between subject characteristics and total anti-HAV seropositivity and anti-HBs seropositivity among healthcare students $(n=650)$

\begin{tabular}{|c|c|c|c|c|c|}
\hline Variables & & $\begin{array}{l}\text { Total Anti-HAV seropositivity Adj. OR }{ }^{a} \\
\text { (Cl 95\%) }\end{array}$ & $p$ & $\begin{array}{l}\text { Anti-HBs seropositivity Adj. OR } \\
\text { (Cl 95\%) }\end{array}$ & $p$ \\
\hline \multirow[t]{2}{*}{ Sex } & Female & Ref & & - & \\
\hline & Male & $1.44(0.98-2.10)$ & 0.057 & - & \\
\hline \multirow[t]{2}{*}{ Age group (years) } & $\leq 20$ & Ref & & $2.48(1.16-5.29)$ & 0.018 \\
\hline & $\geq 21$ & $1.73(1.05-1.86)$ & 0.030 & Ref & \\
\hline \multirow[t]{3}{*}{ Perceived economic position } & High & Ref & & Ref & \\
\hline & Average & $1.61(1.01-2.58)$ & 0.046 & $2.13(1.07-4.24)$ & 0.030 \\
\hline & Low & $2.75(1.31-5.79)$ & 0.007 & $5.41(0.68-43.04)$ & 0.110 \\
\hline \multirow[t]{2}{*}{ House that has the sewage system } & Yes & Ref & & - & \\
\hline & No & $1.38(0.90-2.13)$ & 0.135 & - & \\
\hline \multirow[t]{2}{*}{ Human development index } & High & Ref & & Ref & \\
\hline & Intermediate & $4.37(3.00-6.38)$ & $<0.001$ & $2.32(0.97-5.51)$ & 0.057 \\
\hline \multirow[t]{3}{*}{ Self-reported HBV vaccination history } & No & - & & Ref & \\
\hline & Yes & - & & $8.23(2.08-32.62)$ & 0.003 \\
\hline & Unknown & - & & $1.43(0.61-3.35)$ & 0.400 \\
\hline
\end{tabular}

${ }^{a}$ Adjusted according to sex, age, perceived economic position, a house that has the sewage system and human development index

${ }^{\mathrm{b}}$ Adjusted according to age, perceived economic position, human development index and self-reported HBV vaccination history

seropositivity for total anti-HAV in HCSs was $34.9 \%$. Most of the HCSs (93.7\%) were anti-HBs positive. All of the HCSs were anti-HCV negative. The ratio of antiHAV seropositivity was higher in those $\geq 21$ years old, in those who perceived their economic status to be average and low, and in those who lived in provinces with intermediate HDI levels before attending university. The ratio of total anti-HBs positivity was higher in those $\leq 20$ years old, in those who perceived their economic status to be average and in those who reported a vaccination history against $\mathrm{HBV}$.

In our study, approximately two out of three students were not immune to the HAV. In similar studies in Turkey, anti-HAV seropositivity was reported as 51\% [10], 27.3\% [11] and 15\% [12]. In Korea, anti-HAV seropositivity was reported as $11.4 \%$ among 1st- to 3rd-year medical school students [13], and in medical students in Iran, the prevalence of anti-HAV seropositivity was $70 \%$ in one study [14] and 34\% in another study [15]. In another study from Italy, $3.16 \%$ of nursing students were immune to the HAV [16]. These differences between studies may be attributed to the health behaviors of participants, hygiene, sanitary conditions, and socioeconomic levels of the country.

The incidence rates of HAV infection decrease in children and adolescents, and the risk of HAV infection increases in adults. Serious and severe complications of HAV infection are more common in adults [4]. It is known that the anti-HAV seropositivity rate is associated with increasing age [17]. In our study, the prevalence of anti-HAV seropositivity was significantly higher in students 21 years old and older. However, our results showed that a large number of HCSs lacked natural immunity to HAV infection and were susceptible to the virus. Anti-HAV seropositivity in this study was relatively low compared with that in a study conducted in medical students in the same region in 2005, in which the seroprevalence rate was $64 \%$ [18]. We predict that the average age for HAV infection will shift to older ages with the incrementally changing standard of living in our country. Therefore, the number of susceptible students in the coming years might increase. Since HCSs are at high risk for HAV infection, they should be vaccinated before medical clerkship begins.

In this study, using a univariate analysis (chi-square test), it was determined that anti-HAV seropositivity was significantly higher among male students than among female students. This result was not in agreement with the observations reported in other studies [12, 14, 16, 19]. We have no explanation for this finding. Moreover, this relationship was not observed in the logistic regression analysis.

We found higher total anti-HAV seropositivity in subjects who had lived in a house that did not have a sewage system. Water contaminated with feces from infected humans can potentially spread the HAV [4]. Waterborne transmission is usually associated with sewage-contaminated water. This finding was not statistically significant in the logistic regression analysis.

We found a relationship between anti-HAV seropositivity and socioeconomic indicators, including the HDI and perceived economic position. In our study, low 
socioeconomic status and an intermediate HDI were found to be the most important factors related to antiHAV positivity. In a recent systematic review published in 2017, it was found that economic variables appear to be much better predictors of HAV prevalence than water and sanitation indicators. There is a strong negative correlation between the HDI and HAV prevalence [17]. Our results, specifically the relationship between socioeconomic indicators and anti-HAV seropositivity, are consistent with the results of other studies conducted in medical students $[15,20,21]$ and nursing students [12].

In our study, most students (93.7\%) had immunity against HBV infection. Anti-HBs seropositivity was found in $31.9 \%$ in a study conducted in the general Turkish population in 2009-2010 [8]. The higher anti-HBs seropositivity in our results may be due to the young age of the students. To control HBV infection, many countries have added hepatitis $\mathrm{B}$ vaccination to the expanded program on immunization (EPI). In Turkey, hepatitis B vaccination was added to the EPI in 1998. Moreover, in our study, the anti-HBs seropositivity was 2.7 times higher in students $\leq 20$ years of age than in those older than 20 years of age. These findings can be attributed to the effectiveness of the vaccination program. In our study, the percentage of anti-HBs seropositive HCS was consistent with those reported in some other countries, such as Poland, Mexico, the United States, and Italy [22-25]; nevertheless, it was higher than the results of studies from Saudi Arabia, Taiwan, the United Arab Emirates, Italy, Spain, Palestine, and Iran [21, 26-31]. The anti-HB seropositivity of HCSs is widely distributed (17.0 to $89.4 \%)$ in Turkey [12, 32, 33]. Variation in the prevalence of anti-HBs seropositivity in previous studies conducted in different countries, and even within the same country, may be attributed to differences in the study groups (e.g., first-year students or all students), data collection dates (some studies were conducted in participants who born before the introduction of the hepatitis B vaccine to the EPI), compliance with the immunization program, and socioeconomic status.

In our study, the prevalence of anti-HBs seropositivity was higher in low and intermediate economic groups. We have no explanation for this finding. This relationship was not observed in the low economic group in the logistic regression analysis. Moreover, the 95\% confidence intervals for the results were very large. Therefore, the results should be considered with these limitations in mind. In a population-based study conducted in Turkey, young participants (aged 2-21 years old) with low income were more likely to be vaccinated; inversely, old participants (22-89 years old) with high income were more likely to be vaccinated [9]. Our results and these results may reflect the strength of primary healthcare and the effectiveness of the immunization program in the past 20 years. Since 1998, HBV vaccination for newborns has been done free of charge in Turkey. Therefore, those with low income may be better able to comply with the vaccination program. Furthermore, HBV vaccination has been performed for nonvaccinated children at primary and high schools.

In our study, the prevalence of anti-HBs positivity was significantly higher in participants who declared being vaccinated against HBV. However, most HCSs $(53.2 \%)$ did not remember whether they were vaccinated. Therefore, it may be more accurate to examine anti-HB seropositivity to decide on whether to vaccinate. The 41 unvaccinated $\mathrm{HBsAg} / \mathrm{anti}-\mathrm{HBs} / \mathrm{anti}-\mathrm{HBc}$ seronegative HCSs were immunized with three doses of the hepatitis $B$ vaccine.

Anti-HCV seropositivity was not detected in the HCSs in our study. The prevalence of HCV infection in Turkey is low (approximately 1\%). This might be related to rigorous screening of blood donors for $\mathrm{HBV}$ and $\mathrm{HCV}$ and the low rate of intravenous drug use in Turkey [8]. Our result was consistent with other studies conducted in Saudi Arabia, the United Arab Emirates, Brazil, Palestine, and Turkey [12, 21, 26, 33, 34]. According to these results, HCV infection was not an important health issue among HCSs.

The study limitations are mainly related to data collection. We collected self-reported data regarding sociodemographic characteristics, vaccination history, perceived economic position, place of residence, source of water, and sewage system status. Although self-reporting is an acceptable method of data collection in public health studies, it is associated with potential information bias.

\section{Conclusion}

Approximately two out of three HCSs were susceptible to HAV infection. Since HAV infection can become a serious and even deadly disease in adolescents and adults and HCSs are at high risk for HAV infection, they should be vaccinated before medical clerkships begin. This study showed a high prevalence of anti-HBs seropositivity among HCSs. This result may be largely attributed to the implementation of a successful vaccination program in Turkey during recent decades. Mandatory vaccination should be considered for HCSs before they start their clinical practice.

\section{Abbreviations}

HAV: Hepatitis A virus; HBV: Hepatitis B virus; HCV: Hepatitis C virus; HCSs: Healthcare students; HCWs: Health care workers; HDI: Human development index; WHO: World Health Organization

\section{Acknowledgments}

We thank the nurses at Dokuz Eylül University Hospital for collecting serum samples from the participants. We also thank Deniz Kutluk and Aysegul Gokkaya for their contribution to the study. 


\section{Authors' contributions}

AA was involved in the study design, data collection, statistical analysis, data interpretation, manuscript preparation, and literature search. DC, SK, NE, PB and AAS were involved in the study design, data collection, and manuscript preparation. All the authors have read and approved the final submitted manuscript.

\section{Funding}

This study was financially supported by the Dokuz Eylül University Scientific Research Projects Unit (grant number: 2018.KB.SAG.006). The funding body played no role in the design of the study and collection, analysis, and interpretation of data and in writing the manuscript. The authors have no financial interest in any of the products or devices mentioned in this article.

\section{Availability of data and materials}

The datasets used during the current study are available from the corresponding authors upon reasonable request and with permission from the University of Clinical Research Ethics Committee.

\section{Ethics approval and consent to participate}

The institutional study approval was obtained from the Clinical Research Ethics Committee of Dokuz Eylul University, Izmir, Turkey. Participants were informed of their rights before signing the informed consent form, including the right to withdraw from the study at any time.

\section{Consent for publication}

Not applicable.

\section{Competing interests}

The authors declare that they have no competing interests.

\section{Author details}

'Vocational School of Healthcare, Dokuz Eylul University, Balcova, 35340 Izmir, Turkey. ${ }^{2}$ Department of Microbiology, School of Medicine, Dokuz Eylu University, Izmir, Turkey. ${ }^{3}$ Department of Radiology, School of Medicine, Dokuz Eylul University, Izmir, Turkey.

\section{Received: 24 September 2019 Accepted: 14 July 2020}

Published online: 22 July 2020

\section{References}

1. World Health Organization. Prevention \& Control of Viral Hepatitis Infection: Framework for Global Action. Geneva: World Health Organization; 2012. http://apps.who.int/iris/bitstream/handle/10665/130012/WHO_HSE_PED HIP_GHP_2012.1_eng.pdf?sequence=1 Accessed 11 Jun 2019.

2. Centers for Disease Control and Prevention. Epidemiology and prevention of vaccine- preventable diseases. Hepatitis B; 2018. https://www.cdc.gov/ vaccines/pubs/pinkbook/hepb.html\#hepb Accessed 15 June 2019.

3. World Health Organization. Global Hepatitis Report 2017. Geneva: World Health Organization (WHO); 2017. http://apps.who.int/iris/bitstream/ handle/10665/255016/9789241565455-eng.pdf?sequence=1. Accessed 10 June 2019.

4. World Health Organization. Hepatitis A. https://www.who.int/en/newsroom/fact-sheets/detail/hepatitis-a Accessed 15 Jun 2019.

5. Jacobsen $\mathrm{KH}$, Wiersma ST. Hepatitis a virus seroprevalence by age and world region, 1990 and 2005. Vaccine. 2010;28:6653-7.

6. Turkish Ministry of Health. Viral hepatitis prevention and control program of Turkey (2018-2023). https://kms.kaysis.gov.tr/(X (1)

S(t2fx3bjfkw4034ljzk5borik))/Home/Goster/ 144104?AspxAutoDetectCookieSupport=1 Accessed 1 May 2020.

7. Toy M, Onder FO, Wormann T, Bozdayi AM, Schalm SW, Borsboom GJ, et al. Age- and region-specific hepatitis B prevalence in Turkey estimated using generalized linear mixed models: a systematic review. BMC Infect Dis. 2011; 11:337.

8. Tozun N, Ozdogan O, Cakaloglu Y, Idilman R, Karasu Z, Akarca U, et al. Seroprevalence of hepatitis $B$ and $C$ virus infections and risk factors in Turkey: a fieldwork TURHEP study. Clin Microbiol Infect. 2015;21:1020-6.

9. Kahraman HG, Ozbek OA, Emek M, Atasoylu G, Sekreter O, Unal B. Hepatitis $B$ seroprevalence and the relationship between being hepatitis $B$ vaccinated and infected with social determinants of health: Manisa, 2014. Hepat Mon 2018;18(7):e65395
10. Peker E. Hepatitis A seroprevalence in healthcare students. Hatay, Turkey: Mustafa Kemal University Medical Faculty; 2015. [Unpublished Thesis]. https://tez.yok.gov.tr/UlusalTezMerkezi/TezGoster?key=Br_ XTptK8CZ70f0JGX9xEizJiE00Pvq7zkY6GX_sNRyXU8MkH7scdG9LzpOsAsu-

11. Ergin A, Uzun SU, Bozkurt Al, Til A, Savaş E, Pakyurek H, et al. Hepatitis a seroprevalence and contributing factors in the sixth year medical faculty students. TAF Prev Med Bull. 2013;12:625-32.

12. Kader C, Yolcu S, Erbay A, Kilic Akca N, Yuzer S, Polat S. Investigation of hepatitis-B and $C$ seroprevalences in Bozok University School of health students. Viral Hepat J. 2013;19:49-53.

13. Kim S, Lee $\mathrm{JH}$, Hwang JH, Lee CS. Hepatitis A antibody seroprevalence among medical school students. Am J Infect Control. 2011;39:889-90.

14. Vakili B, Rahimi H, Ataei B, Janghorbani M, Khorvash F, Shoaei $P$, et al. Hepatitis A seropositivity among newly admitted medical students of Isfahan, Kermanshah, and Hamedan: a seroprevalence study. J Res Med Sci. 2014;19(Suppl 1):S9-S12.

15. Hosseini Shokouh SJ, Dadashi A, Abiri M, Zohrevand I, Eshraghian A Khoshdel A, et al. HAV immunity in Iranian medical students. Hepat Mon. 2015;15:e26219.

16. Campagna M, Mereu NM, Mulas L, Pilia R, Piazza MF, Spada L, et al. Pattern of hepatitis A virus epidemiology in nursing students and adherence to preventive measures at two training wards of a university hospital. Hepat Mon. 2016;16:e34219.

17. Koroglu M, Jacobsen KH, Demiray T, Ozbek A, Erkorkmaz U, Altindis M. Socioeconomic indicators are strong predictors of hepatitis a seroprevalence rates in the Middle East and North Africa. J Infect Public Health. 2017;10:513-7.

18. Oncu S, Oncu S, Sakarya S. Hepatitis A and B seropositivity among medical students. Health Policy. 2005;74:39-45.

19. Saneian $H$, Rahimi $H$, Shoaei $P$. Hepatitis a seropositivity among first-year students of the Medical University in Isfahan, Iran. Int J Prev Med. 2014; 5(Suppl 3):S208-12.

20. Hoseini SG, Kelishadi R, Ataei B, Yaran M, Motlagh ME, Ardalan G, et al. Seroprevalence of hepatitis a in Iranian adolescents: is it time to introduce a vaccine? Epidemiol Infect. 2016;144:291-6.

21. Sheek-Hussein M, Hashmey R, Alsuwaidi AR, Al Maskari F, Amiri L, Souid AK, et al. Seroprevalence of measles, mumps, rubella, varicella-zoster and hepatitis A-C in Emirati medical students. BMC Public Health. 2012; 12:1047.

22. Slusarczyk J, Małkowski P, Bobilewicz D, Juszczyk G. Cross-sectional, anonymous screening for asymptomatic HCV infection, immunity to HBV, and occult HBV infection among health care workers in Warsaw, Poland. Przegl Epidemiol. 2012;66:445-51.

23. Cárdenas-Perea ME, Gómez-Conde E, Santos-López G, et al. Hepatitis B surface antibodies in medical students from a public university in Puebla, Mexico. Hum Vaccin Immunother. 2016;12:1857-62.

24. Spradling PR, Williams RE, Xing J, Soyemi $K$, Towers J. Serologic testing for protection against hepatitis $B$ virus infection among students at a health sciences university in the United States. Infect Control Hosp Epidemiol. 2012;33:732-6

25. Lamberti M, De Rosa A, Garzillo EM, Corvino AR, Sannolo N, De Pascalis S, et al. Vaccination against hepatitis b virus: are Italian medical students sufficiently protected after the public vaccination programme? J Occup Med Toxicol. 2015;10:41

26. Alqahtani JM, Abu-Eshy SA, Mahfouz AA, El-Mekki AA, Asaad AM. Seroprevalence of hepatitis $B$ and $C$ virus infections among health students and health care workers in the Najran region, southwestern Saudi Arabia: the need for national guidelines for health students. BMC Public Health 2014;14:577.

27. Lin CC, Chang CK, Huang YL, Tseng HF. Low seroprevalence of hepatitis B surface antibody among nursing students in Taiwan: an implication for boosting. Vaccine. 2007;25:8508-11.

28. Sernia S, Ortis M, Antoniozzi T, Maffongelli E, La Torre G. Levels of anti-HBs antibody in HBV-vaccinated students enrolled in the faculty of medicine, dentistry and health professions of a large Italian University. Biomed Res Int. 2015:2015:712020

29. Dini G, Toletone A, Barberis I, Debarbieri N, MassaE PC, et al. Persistence of protective anti-HBs antibody levels and anamnestic response to HBV booster vaccination: a cross-sectional study among healthcare students 20 years following the universal immunization campaign in Italy. Hum Vaccin Immunother. 2016;13:440-4. 
30. Dumaidi K, Al-Jawabreh A. Persistence of anti-HBs among Palestinian medical students after 18-22 years of vaccination: a cross-sectional study. Hepat Mon. 2015;15:e29325.

31. Arias-Moliz MT, Rojas L, Liébana-Cabanillas F, Bernal C, Castillo F, RodríguezArchilla A, et al. Serologic control against hepatitis B virus among dental students of the University of Granada, Spain. Med Oral Patol Oral Cir Bucal. 2015;20:e566-71.

32. Goktalay $T$, Cengiz OB. Seroprevalence of hepatitis $B$ and the hepatitis $B$ knowledge level of the university and vocational school students studying at health professional training at Celal Bayar University. Viral Hepat J. 2010; 15:13-21.

33. Irmak Z, Ekinci B, Akgul AF. Hepatitis B and C seropositivity among nursing students at a Turkish university. Int Nurs Rev. 2010;57:365-9.

34. Scaraveli NG, Passos AM, Voigt AR, Livramento A, Tonial G, Treitinger A. Seroprevalence of hepatitis B and hepatitis $C$ markers in adolescents in Southern Brazil. Cadernos Saúde Pública. 2011;27:753-8.

\section{Publisher's Note}

Springer Nature remains neutral with regard to jurisdictional claims in published maps and institutional affiliations.

Ready to submit your research? Choose BMC and benefit from:

- fast, convenient online submission

- thorough peer review by experienced researchers in your field

- rapid publication on acceptance

- support for research data, including large and complex data types

- gold Open Access which fosters wider collaboration and increased citations

- maximum visibility for your research: over $100 \mathrm{M}$ website views per year

At BMC, research is always in progress.

Learn more biomedcentral.com/submissions 